\title{
The role of COX-2 gene variants on the disease mechanism of inflammatory bowel disease in a Turkish population
}

\author{
Türk toplumundaki inflamatuar bağırsak hastalığının hastalık mekanizmasında COX-2 gen \\ varyantlarının rolü
}

\author{
Elif Sinem İplik $^{1}$, Resul Kahraman ${ }^{2}$, Barış Ertuğrul ${ }^{3}$, Gonca Candan ${ }^{3}$, Arzu Ergen ${ }^{3}$, Bedia Çakmakoğlu ${ }^{3}$
}

\begin{abstract}
Aim: Inflammatory bowel disease has two major types: Crohn's disease and ulcerative colitis that occur in the gastrointestinal tract with unknown etiology. COX-2 has important role on carcinogenesis process including colon cancer supporting the tumor growth. COX-2 was also known due to its ability to change homeostasis on colonic mucosa in inflammatory cells on patients who have inflammatory bowel disease. In this study, we have aimed to find a linkage between inflammatory bowel disease and COX-2 in a Turkish population.

Methods:A total of 106 patients, 42 with Crohn's disease and 64 with ulcerative colitis and 121 healthy contro subjects were included the study. Gene variants of $\mathrm{COX}-2-765 \mathrm{G} \rightarrow \mathrm{C}$ and $\mathrm{COX}-2-1195 \mathrm{~A} \rightarrow \mathrm{G}$ were analyzed by polymerase chain reaction and restriction fragment length polymorphism techniques.

Results: The results demonstrated that COX $-2-1195 \mathrm{~A} \rightarrow \mathrm{G}$ gene variants AA carriers were statistically found in high level on patients with both ulcerative colitis $(\mathrm{p}=0.001)$ and Crohn's disease $(\mathrm{p}=0.008)$. In contrast, AG genotype and $\mathrm{G}$ carriers were statistically found higher in control group (Crohn's disease, $\mathrm{p}=0.005$ for $\mathrm{AG}$ and $\mathrm{p}=0.008$ for $\mathrm{G}$; ulcerative colitis, $\mathrm{p}=0.001$ for $\mathrm{AG}$ and $\mathrm{p}=0.001$ for $\mathrm{G}$ ).

Conclusion: In this research, we have observed important and questionable results between inflammatory bowe disease and COX-2, especially COX-2-1195A $\rightarrow \mathrm{G}$ gene variants AA carriers in a Turkish population Researches need to focus on their local roles on inflammatory bowel disease pathogenesis with large sample size.

Keywords: COX-2, gene variants, Crohn's disease, ulcerative colitis
\end{abstract}

Öz

Amaç: İnflamatuar bağırsak hastalığı, gastrointestinal sistemde etiolojisi tam olarak bilinmeyen bir hastalık grubu olup, Crohn hastalığı ve ülseratif kolit olmak üzere iki önemli tipe ayrılmaktadır. COX-2 kolon kanserinin de dahil olduğu karsinogenez prosesinde rolü olan ve tümör gelişimine katkı sağlayan bir mediatördür. Ayn zamanda, inflamasyon meydana geldiğinde kolonik mukoza üzerindeki stabiliteyi değiştirdiği bilinmektedir. $\mathrm{Bu}$ amaçla, çalıșmamızda inflamatuar barsak hastalığı ile COX-2 ilișkisinin Türk kökenli kișiler üzerinde araştırılması amaçlanmıştır.

Yöntemler: Çalışmaya 42 Crohn ve 64 ülseratif kolitli hasta olmak üzere toplam 106 hasta) ve 121 sağlıkl kontrol dahil edilmiştir. COX-2 $-765 \mathrm{G} \rightarrow \mathrm{C}$ ve COX-2 $-1195 \mathrm{~A} \rightarrow \mathrm{G}$ gen varyantları polimeraz zincir reaksiyonu ve restriksiyon parça uzunluk polimorfizmi teknikleri kullanılarak analiz edilmiştir.

Bulgular: COX-2-1195A $\rightarrow$ G gen varyantı AA taşıyıcılarının istatistiksel olarak hasta grubunda (Crohn hastalı̆ için $\mathrm{p}=0,008$ ve ülseratif kolit için $\mathrm{p}=0,001$ ) kontrol grubuna göre yüksek bulunmuştur. Buna karş1lık olarak $A G$ genotipi ve $\mathrm{G}$ taşıyıcıları da kontrol grubunda anlamlı olarak yüksek bulunmuştur (Crohn hastalığı: $\mathrm{p}=0,005 \mathrm{AG}$ için ve $p=0,008 \mathrm{G}$ için; ülseratif kolit: $p=0,001 \mathrm{AG}$ için ve $\mathrm{p}=0,001 \mathrm{G}$ için).

Sonuç: Çalışmada Türk kökenli kişiler üzerinde, inflamatuar bağırsak hastalığı ve COX-2 arasındaki ilişkiye dair COX-2-1195A $\rightarrow$ G AA taşıyıcıları gibi önemli ve araştırılması gerekli soruları beraberinde getiren bulgular elde edilmiştir. Hasta sayısının arttırılarak ek çalışmalar ile hastalık patogonezindeki rolünün tam olarak araştırılması gerektiği düşünülmektedir.

Anahtar Kelimeler: COX-2, gen varyantları, Crohn hastalığı, ülseratif kolit.
${ }^{1}$ Department of Pharmaceutical Microbiology, Faculty of Pharmacy, Istanbul Yeni Yuzyil University, Istanbul, Turkey

${ }^{2}$ Department of Gastroenterology, Umraniye Education and Resarch Hospital, University of Health Sciences, Istanbul, Turkey

3 Department of Molecular Medicine, Aziz Sancar Institute of Experimental Medicine, Istanbul University, Istanbul, Turkey

Ethics Committee Approval: The study wass approved by the local ethical authority.

Etik Kurul Onayı: Çalıșma lokal etik komite tarafindan onaylanmıştır.

Conflict of Interest: No conflict of interest was declared by the authors.

Çıkar Çatışması: Yazarlar çıkar çatışması bildirmemişlerdir.

Financial Disclosure: The authors declared that this study has received no financial support.

Finansal Destek: Yazarlar bu çalıșma için finansal destek almadıklarını beyan etmişlerdir.

Geliş Tarihi / Received: 17.04.2018

Kabul Tarihi / Accepted: 21.04.2018

Yayın Tarihi / Published: 24.04.2048

Sorumlu yazar / Corresponding author Assist. Prof. Dr. Resul Kahraman

Department of Gastroenterology Umraniye Education and Research Hospital, Istanbul, Turkey

Phone: +90 2166321818

e-posta: drkahraman@hotmail.com

Copyright $(C)$ ACEM 


\section{Introduction}

Inflammatory bowel disease (IBD) is a common condition and chronic inflammatory disease of the gastrointestinal tract with its unclear etiology such as environmental factors, genetics and immunity [1]. IBD has two major phenotypes which have been identified with their clinical and histopathological features: Crohn's disease (CD) and ulcerative colitis (UC). They have been also characterized by recurrent episodes of remission and exacerbation. According to recent studies, IBD could be resulted as colorectal cancer that's one of the reasons why the diseases have still some important questions to solve using genetic factors [2-4].

IBD has different processes in its types such as clinical course and response to the treatment. There are several studies that support these genetic differences could cause the diversities on CD and UC [5]. Nevertheless, UC and CD might be treatable by several medications and surgery [6-8].

To take precautions and prevent the colorectal cancer and related disease, researches still need to focus on underlying mechanisms of the diseases including their genetic roles. As discussed, it is important to understand and solve the etiology of IBD not only because it affects the daily life but also it could end up colon cancer.

Cyclooxygenase (COX) is an enzyme that has important role such as rate-limiting step on not only biosynthesis of prostaglandins and thromboxanes but also lipid mechanisms. COX has two major isoforms as COX-1 and COX-2. While COX-1 is to be found in normal tissues, COX-2 belongs to the expression of some hormones, cytokines and growth factors [810]. COX-2 and its relation to carcinogenesis are well known in several cancers including colon cancer. COX-2 leads to tumor growth by increasing the expression vascular endothelial growth factor (VEGF) of colon cancer cells [11]. COX-2-765G $\rightarrow \mathrm{C}$ and $\mathrm{COX}-2-1195 \mathrm{~A} \rightarrow \mathrm{G}$ are mostly studied as promoter gene variants. Their polymorphisms could cause to modify COX-2 transcription and mRNA levels [12].

We hypothesized that COX-2 gene polymorphisms which is well known for several cancers, might affect by facilitating immune response shift in tumor microenvironment and it might be associated with IBD by altering the inflammatory response. For this purpose, we aimed to show the relations of $\mathrm{COX}-2-765 \mathrm{G} \rightarrow \mathrm{C}$ and $\mathrm{COX}-2-1195 \mathrm{~A} \rightarrow \mathrm{G}$ polymorphisms on IBD in a Turkish population for the first time.

\section{Material and methods}

Subjects

A total of 227 subjects including 106 patients suffering from IBD (42 CD and 64 UC) and 121 healthy control subjects were studied in our research after obtaining written informed consent from the participants and approval from Istanbul University's Ethics Committee based on World Medical Association Declaration of Helsinki.

Demographic data including age and gender were evaluated. Biochemical parameters i.e. serum albumin $(\mathrm{mg} / \mathrm{dL})$, C-reactive protein $(\mathrm{CRP})(\mathrm{mg} / \mathrm{L})$ and sedimentation rate $(\mathrm{mm} / \mathrm{h})$ were measured from the blood samples. In addition, pathological features of the patients with $\mathrm{UC}$ and $\mathrm{CD}$ in relation with the disease extension, localization and behavior were analyzed. Clinical and demographic data of the patients and the control group are given in Table 1 . products

Amplification of DNA and analysis of digested

Blood samples from all patients and the control were collected and genomic DNA was extracted from peripheral whole blood by Invitrogen Purelink Genomic DNA technique.
Polymerase chain reaction (PCR)/restriction fragment length polymorphism (RFLP) analysis was performed for the detection of the gene variants of $\mathrm{COX}-2-765 \mathrm{G} \rightarrow \mathrm{C}$ and $\mathrm{COX}-2$ $1195 \mathrm{~A} \rightarrow \mathrm{G}$. The primers to amplify genes and the enzymes to detect digested reaction are given in Table 2 . The products were analyzed on $2 \%$ agarose gel stained with ethidium bromide and examined under transillumination.

Statistical analysis

The statistical analyses were performed using the SPSS 21.0 statistical software package (SPSS, Chicago, IL). P values lower than 0.05 were assumed to be statistically significant. We compared the cases and the controls in biochemical parameters using Student's t test. One-way Anova test was used to investigate the biochemical parameters between the genotypes. Categorical variables such as genotypes and alleles were compared using Chi- Square $(\chi 2)$ test. The Odds Ratios and the confidence intervals were calculated as an estimate of the relative risk.

Table 1: Clinical and demographical parameters of the patients.

\begin{tabular}{|c|c|c|c|c|}
\hline Clinical Parameters & $\begin{array}{c}\mathrm{UC} \\
(\mathrm{n}=64) \\
\end{array}$ & $(n=42)$ & $\begin{array}{c}\text { All } \\
\text { patients } \\
(n=106)\end{array}$ & Controls \\
\hline Age $\left(\right.$ year) ${ }^{\beta}$ & $42.2 \pm 15.3$ & $39.8 \pm 9.7$ & $42.6 \pm 13.5$ & $40.3 \pm 9.9$ \\
\hline Sex(Male/Female) & $31 / 33$ & $19 / 23$ & $50 / 56$ & $30 / 91$ \\
\hline $\mathrm{CRP}(\mathrm{mg} / \mathrm{L})^{\beta}$ & $1.0 \pm 3.3$ & $1.2 \pm 1.9$ & $1.1 \pm 2.9$ & NA \\
\hline $\operatorname{Albumin}(\mathrm{mg} / \mathrm{dl})^{\beta}$ & $5.0 \pm 4.7$ & $4.3 \pm 0.4$ & $4.7 \pm 3.6$ & NA \\
\hline Sedimentation $(\mathrm{mm} / \mathrm{h})^{\beta}$ & $26.6 \pm 20.4$ & $27.8 \pm 21.7$ & $27.1 \pm 20.8$ & NA \\
\hline \multicolumn{5}{|l|}{$\begin{array}{l}\text { Demographical } \\
\text { Parameters }\end{array}$} \\
\hline Disease extension in UC & & & NA & NA \\
\hline Proctitis ${ }^{\alpha}$ & $30(47.6)$ & NA & & \\
\hline Left-sided colitis ${ }^{\alpha}$ & $15(23.8)$ & NA & & \\
\hline Extensive colitis ${ }^{\alpha}$ & $18(28.6)$ & NA & & \\
\hline Disease localization in CD & & & NA & NA \\
\hline Ileal $^{\alpha}$ & NA & $16(38.1)$ & & \\
\hline Ileocolonic $^{\alpha}$ & NA & $21(50)$ & & \\
\hline Colonic $^{\alpha}$ & NA & $5(11.9)$ & & \\
\hline Disease behavior in CD & & & NA & NA \\
\hline Inflammatory $^{\alpha}$ & NA & $20(47.6)$ & & \\
\hline Penetrating ${ }^{\alpha}$ & NA & $9(21.4)$ & & \\
\hline Stricturing ${ }^{\alpha}$ & NA & $12(28.6)$ & & \\
\hline Penetrating \& stricturing ${ }^{\alpha}$ & NA & $1(2.4)$ & & \\
\hline
\end{tabular}

${ }^{\beta}:$ mean \pm standard deviation, ${ }^{\alpha}: \mathrm{n}(\%)$

n: number of subjects, CRP: C reactive protein, CD: Crohn's disease, UC: ulcerative colitis, NA: not applicable.

\section{Results}

There were no significant differences between the groups in terms of age $(\mathrm{p}=0.070)$.

In Table 3, the genotype and allele frequencies of COX$2-765 \mathrm{G} \rightarrow \mathrm{C}$ and $\mathrm{COX}-2-1195 \mathrm{~A} \rightarrow \mathrm{G}$ are given. Although there were no statistically significant differences on COX-2-765 $\mathrm{G} \rightarrow \mathrm{C}$ genotype and allele frequencies $(\mathrm{p}=0$.) $90, \mathrm{COX}-2-1195 \mathrm{~A} \rightarrow \mathrm{G}$ have come up statistically significant results on patients with both UC and CD that carrying the AA genotype compared with the control group [(all patient/control $=(\mathrm{p}=0,001 ; \chi 2=16.70$; $\mathrm{OR}=3.17 ; 95 \% \mathrm{Cl}=1.80-5.58) ; \mathrm{CD} / \mathrm{control}=\left(\mathrm{p}=0.008 ; \chi^{2}=6.92 ;\right.$ $\mathrm{OR}=2.71 ; 95 \% \mathrm{Cl}=1.27-5.79) ; \mathrm{UC} /$ control $=(\mathrm{p}=0.001 ; \chi 2=14.06$; $\mathrm{OR}=3.54 ; 95 \% \mathrm{Cl}=1.79-7.00)]$.

In the control group, AG genotype and $\mathrm{G}$ allele carriers were statistically higher with respect to the patient groups $[\mathrm{AG}=$ $(\mathrm{p}=0.001 ; \quad \chi 2=19.63 ; \quad \mathrm{OR}=2.26 ; 95 \% \quad \mathrm{Cl}=1.52-3.35), \quad \mathrm{G}=$ $(\mathrm{p}=0.001 ; \chi 2=16.70 ; \quad \mathrm{OR}=2.04 ; 95 \% \quad \mathrm{Cl}=1.41-2.95)] \quad \mathrm{CD}$ $[\mathrm{AG}=(\mathrm{p}=0.005 ; \quad \chi 2=7.91 ; \quad \mathrm{OR}=1.95 ; \quad 95 \% \quad \mathrm{Cl}=1.14-3.34)$, $\mathrm{G}=(\mathrm{p}=0.008 ; \chi 2=6.92 ; \mathrm{OR}=1.82 ; 95 \% \mathrm{Cl}=1.09-3.02)]$ and for $\mathrm{UC}[\mathrm{AG}=(\mathrm{p}=0.001 ; \chi 2=16.61 ; \mathrm{OR}=2.52 ; 95 \% \mathrm{Cl}=1.50-4.22)$, $\mathrm{G}=(\mathrm{p}=0.001 ; \chi 2=14.06 ; \mathrm{OR}=2.21 ; 95 \% \mathrm{Cl}=1.38-3.57)]$. 
When we examined the patient groups between UC and $\mathrm{CD}$, there was no significant difference in terms of distribution of both genotypes $(\mathrm{p}=0.20)$. Each of the patient and control groups was checked for all polymorphisms by the HardyWeinberg equilibrium. According to Hardy-Weinberg equilibrium, the frequency of COX-2-1195A $\rightarrow \mathrm{G}$ genotypes in the control subjects was not in the Hardy-Weinberg equilibrium.

Table 2. Procedure of the primers to amplify DNA and analysis of digested products.

\begin{tabular}{|c|c|c|}
\hline $\begin{array}{l}\text { Gene } \\
\text { variants }\end{array}$ & $\mathrm{COX}-2765 \mathrm{G} \rightarrow \mathrm{C}$ & $\mathrm{COX}-21195 \mathrm{~A} \rightarrow \mathrm{G}$ \\
\hline Primers & $\begin{array}{l}5 '- \\
\text { TATTATGAGGAGAATTACTCGC } \\
-3,\end{array}$ & $\begin{array}{l}\text { '- } \\
\text { CCCTGAGCACTACCCATGAT-3, }\end{array}$ \\
\hline & $\begin{array}{l}5 \text { '- } \\
\text { GCTAAGTTGCTCACAGAGAT-3, }\end{array}$ & $\begin{array}{l}5 \text { '- } \\
\text { GCCTTCATAGGAGATACTGG-3, }\end{array}$ \\
\hline Enzyme & Aci I & Pvu II \\
\hline Product & $\begin{array}{c}\text { CC }-301 \text { bp } \\
\text { GG }-209 \text { and } 100 b p \\
\text { GC }-309,209,100 b p\end{array}$ & $\begin{array}{c}\text { AA - } 273 \text { bp } \\
\text { AG - } 273 \text { and } 220 b p \\
\text { GG }-220 \text { bp }\end{array}$ \\
\hline
\end{tabular}

Table 3: Distribution of COX-2-765 G $\rightarrow \mathrm{C}$ and COX-2-1195A $\rightarrow \mathrm{G}$ gene variants in the study groups.

\begin{tabular}{|c|c|c|c|c|}
\hline & $\begin{array}{c}\mathrm{UC} \\
(n=64)\end{array}$ & $\begin{array}{c}\text { CD } \\
(n=42)\end{array}$ & $\begin{array}{c}\text { All } \\
\text { Patients } \\
(n=106)\end{array}$ & $\begin{array}{c}\text { Controls } \\
(n=121)\end{array}$ \\
\hline $\begin{array}{l}\mathrm{COX}-2 \\
765 \mathrm{G} \rightarrow \mathrm{C}\end{array}$ & & & & \\
\hline $\mathrm{GG}^{\alpha}$ & $39(60) 9$. & $28(66.7)$ & $67(63.2)$ & $73(60.3)$ \\
\hline $\mathrm{CC}^{\alpha}$ & $1(1.6)$ & $3(7.1)$ & $4(3.8)$ & $5(4.1)$ \\
\hline $\mathrm{GC}^{\alpha}$ & $24(37.5)$ & $11(26.2)$ & $35(33)$ & $43(35.5)$ \\
\hline $\mathrm{G}^{\alpha}$ & $102(59.3)$ & $67(59.5)$ & $169(59)$ & $189(56.1)$ \\
\hline $\mathrm{C}^{\alpha}$ & $26(40.6)$ & $17(40.4)$ & $43(40.5)$ & $53(43.8)$ \\
\hline $\begin{array}{l}\mathrm{COX}-2 \\
1195 \\
\mathrm{~A} \rightarrow \mathrm{G}\end{array}$ & & & & \\
\hline $\mathrm{AA}^{\alpha}$ & $49(76.6)^{* * *}$ & $30(71.4)^{* * * *}$ & $79(74.5)^{*}$ & $58(47.9)$ \\
\hline $\mathrm{GG}^{\alpha}$ & $2(3.1)$ & $1 /(2.4)$ & $3(2.8)$ & $1(0.8)$ \\
\hline $\mathrm{AG}^{\alpha}$ & $13(20.3)$ & $11(26.2)$ & $24(22.6)$ & $62(51.2)^{*}, * * * * * *$ \\
\hline $\mathrm{A}^{\alpha}$ & $111(86.7)$ & $71(84.5)$ & $182(90)$ & $178(73.5)$ \\
\hline $\mathrm{G}^{\alpha}$ & $17(13.3)$ & $13(15.5)$ & $30(10)$ & $64(26.5) *, * *, * * *$ \\
\hline
\end{tabular}

$: \mathrm{n}(\%)$

$\mathrm{n}=$ number of subjects, CD: Crohn's disease, UC, ulcerative colitis, *:all patients/control, **:CD/control, ***:UC/ control

\section{Discussion}

IBD is well known with their linkage between colorectal cancer $[13,14]$. To have both UC and CD, this condition might lead to cancer in a long-term period $[15,16]$. COX-2 is an enzyme that has a lot of regular activities in biosynthesis and lipid mechanisms. COX-2 also has the ability to let tumor growth by its potential of being expressed VEGF of colon cancer [11]. It is important to diagnose and have suitable treatments for IBD not only because it has not ignorable effect on daily life but also it has a big risk for colorectal cancer. COX2 is lightening up with his potential for promising target to treatment options for colorectal cancer $[17,18]$. COX-2 and IBD are underlined the colorectal cancer in somehow with their unclear role on the pathway. We have wanted to seek a correlation between them in Turkish patients.

There are several connections with IBD and colorectal cancer, colorectal cancer and COX-2, IBD and COX-2 in the way of directly or indirectly. If COX-2 might be potential of being the candidate for early prediction for colorectal cancer for whom suffering from IBD and have COX-2 related polymorphisms. In addition, polymorphisms are important for prediction not only because it results quickly in the laboratory analysis by simple samples of the patients such as blood; but, also it is cheaper than other analyzes such as biopsies. That is the reason of importance of finding a risk linkage for IBD and COX-2 to avoid colorectal cancer as prevention. One way of the mechanism with COX-2 and IBD is related with the inflammation. According to our results, it is hypothesized that tumor microenvironment and COX-2 interaction are related with IBD's etiology. COX-2 gene variants might affect the inflammatory response.

Due to our results, COX-2-1195A $\rightarrow$ G AA genotypes ended up statistically a risk factor not only for all patients but also between UC and CD. In addition, our results claim that AG genotype and $\mathrm{G}$ allele have protective role. There are studies that have supportive result for our study such as COX-2 was found to strongly induce the inflammatory cells of IBD patients on their colonic mucosa [19, 20]. Singer et al. [20] have worked on both COX-1 and COX-2 expression in all IBD cases (including UC, $\mathrm{CD}$ and healthy tissues). Their results ended up important results by COX-2 expression in UC and CD patients. Singer also hypothesized that COX-2 expression level could be linked to turn the healthy cells to carcinogenesis process [20]. When gastrointestinal homeostasis becomes weak, it results in adverse reaction of nonsteroidal anti-inflammatory drugs (NSAIDs) for users, which triggered the inhibition of prostaglandin syntheses such as COX-1 and COX-2 [21, 22]. In this weak condition, while COX-1 inhibition is started, COX-2 selective inhibitors may be expected to reduce the incidence of gastrointestinal adverse reaction while retaining the anti-inflammatory effects [22-24]. Although, it is known by some research that COX-2 and its related proteins help to recover the intestine when fistula needs healing process by working for angiogenesis [25-28].

Anderson et al. [29] have studied with COX-2 gene variants in a Scottish and Danish case-control study including 732 CD cases, 973 UC cases, and 1157 healthy controls. They have resulted with COX-2 A-1195G variant allele that had increased risk of UC and also they have claimed that carriers the variant have risk for UC before the age of 40. Zhang et al. [30] have also worked with both COX-2-1195G/A (A/A) and MnSOD9Ala/Val (V/V) in only 750 UC patients and 750 healthy subjects. Their results have ended up statistically increased results in UC patients with COX-2-1195G/A (A/A) genotype and they have also suggested that high-fat diet related the polymorphism in COX-2-1195G/A (A/A) for UC patients. De Vries et al. [31] have studied with COX-2 gene variants including COX-2 -1195 and COX-2 765 in Dutch IBD patients. They have only found the reduced association for risk of $\mathrm{CD}$ with COX-2 765 G C polymorphism.

COX-2 has the role to alter enzyme expression levels or impact biochemical function [32]. COX-2 might also be promoted by cytokines, growth factor, and oncogenes. When polymorphisms occur in $\mathrm{COX}-2$, it could cause cellular over expression and effective to get failure the enzyme [33]. COX-2 has well understandable protective role in intestinal physiology [34] but its cellular and pathophysiological molecular mechanisms are remaining still unclear. That is the reason our study might have an answer for molecular way with Turkish patients by finding $\mathrm{COX}-2-1195 \mathrm{~A} \rightarrow \mathrm{G}$ AA as a risk factor for all patients in both UC and CD.

The study has some potential limitations that make the study limited power even though the important results. Big sample size and further analyses might be helpful to find an answer for underlying mechanism of IBD and its relation with COX-2 genotypes. 
Our study is ended up supportive and statistically important result for the literature with Turkish patients for the first time. The area needs to be lightened by further studies on pathophysiological molecular mechanism.

\section{References}

1. Sleizenger \& Fordtran's, Gastrointestinal and Liver Disease 7th Edition, Saunders Elsevier, Philadelphia .Volume I, pp. 2005-67.

2. Peña-Sánchez JN, Lix LM, Teare GF, Li W, Fowler SA, Jones JL. Impact of an Integrated Model of Care on Outcomes of Patients With Inflammatory Bowel Diseases: Evidence From a Population-Based Study. J Crohns Colitis. 2017;11:1471-9

3. Eaden JA, Abrams KR, Mayberry JF. The risk of colorectal cancer in ulcerative colitis: a meta-analysis. Gut. 2001;48:526-35.

4. Higashi D, Futami K, Ishibashi Y, Egawa Y, Maekawa T, Matsui T, Iwashita A, et al. Clinical course of colorectal cancer in patients with ulcerative colitis. Anticancer Res. 2011;31:2499-504.

5. Lesage S, Zouali H, Cézard JP, Colombel JF, Belaiche J, Almer S, et al. CARD15/NOD2 mutational analysis and genotype-phenotype correlation in 612 patients with inflammatory bowel disease. Am J Hum Genet. 2002;70:845-57.

6. Olén O, Askling J, Sachs MC, Frumento P, Neovius M, Smedby KE, et al. Childhood onset inflammatory bowel disease and risk of cancer: a Swedish nationwide cohort study 1964-2014. BMJ. 2017;20:358:j3951.

7. Jewel Samadder N, Valentine JF, Guthery S, Singh H, Bernstein CN, Wan Y, et al. Colorectal Cancer in Inflammatory Bowel Diseases: A Population-Based Study in Utah. Dig Dis Sci. 2017;62:2126-32.

8. Luo C, Zhang H. The Role of Proinflammatory Pathways in the Pathogenesis of Colitis-Associated Colorectal Cancer. Mediators Inflamm. 2017;2017:5126048.

9. Rutter M, Saunders B, Wilkinson K, Rumbles S, Schofield G, Kamm $\mathrm{M}$, et al. Severity of inflammation is a risk factor for colorectal neoplasia in ulcerative colitis. Gastroenterology. 2004;126:451-9.

10. Wang R, Leong RW. Primary sclerosing cholangitis as an independent risk factor for colorectal cancer in the context of inflammatory bowel disease: a review of the literature. World J Gastroenter. 2014;20:87839.

11. Watanabe T, Konishi T, Kishimoto J, Kotake K, Muto T, Sugihara K, et al. Ulcerative colitis-associated colorectal cancer shows a poorer survival than sporadic colorectal cancer: a nationwide Japanese study. Inflamm Bowel Dis. 2011;17:802-8.

12. Zhang X, Miao X, Tan W, Ning B, Liu Z, Hong Y. Identification of functional genetic variants in cyclooxygenase- 2 and their association with risk of esophageal cancer. Gastroenterology. 2005;129:565-76.

13. Bernstein CN, Blanchard JF, Kliewer E, Wajda A. Cancer risk in patients with inflammatory bowel disease: a population based study. Cancer. 2001;91:854-62.

14. Goldacre MJ, Wotton CJ, Yeates D, Seagroatt V, Jewell D. Cancer in patients with ulcerative colitis, Crohn's disease and coeliac disease: record linkage study. Eur J Gastroenterol Hepatol. 2008;20:297-304.

15. Beaugerie L, Svrcek M, Seksik P, Bouvier AM, Simon T, Allez M, et al. CESAME Study Group. Risk of colorectal high-grade dysplasia and cancer in a prospective observational cohort of patients with inflammatory bowel disease. Gastroenterology. 2013;145:166-175.e8.

16. Askling J, Dickman PW, Karlén P, Broström O, Lapidus A, Löfberg R,et al. Family history as a risk factor for colorectal cancer in inflammatory bowel disease. Gastroenterology. 2001;120:1356-62.

17. Thompson PA, Ashbeck EL, Roe DJ, Fales L, Buckmeier J, Wang F, et al. Celecoxib for the Prevention of Colorectal Adenomas: Results of a Suspended Randomized Controlled Trial. J Natl Cancer Inst. 2016;108:pii:djw151.

18. Li P, Wu H, Zhang H, Shi Y, Xu J, Ye Y, et al. Aspirin use after diagnosis but not prediagnosis improves established colorectal cancer survival: a meta-analysis. Gut. 2015;64:1419-25.

19. Connell W, Leong RW, Walsh A, Kamm M, Kench J, What should be the protocol to manage indefinite dysplasia in IBD? http://wiki.cancer.org.au/australiawiki/index.php?oldid=17938, 2012.

20. Singer II, Kawka DW, Schloemann S, Tessner T, Riehl T, Stenson WF, Cyclooxygenase 2 is induced in colonicepithelial cells in inflammatory bowel disease. Gastroenterology. 1998;115:297-306.

21. Smythe EM, Burke A, FitzGerald GA. Lipid-derived autacoids: eicosanoids and platelet-activating factor. In: Goodman \& Gilman's The Pharmacological Basis of Therapeutics, edited by Brunton LL, Lazo JS, Parker KL. New York: McGraw-Hill, 2005, pp. 653-70.
22. Patrignani P, Panara MR, Sciulli MG, Santini G, Renda G, Patrono C Differential inhibition of human prostaglandin endoperoxide synthase1 and -2 by nonsteroidal anti-inflammatory drugs. J Physiol Pharmacol. 1997;48:623-31.

23. Vane JR, Botting RM. New insights into the mode of action of antiinflammatory drugs. Inflamm Res. 1995;44:1-10.

24. Needleman P, Isakson PC. The discovery and function of COX-2. J Rheumatol. 1997;49:6-8.

25. Jones MK, Wang H, Peskar BM, Levin E, Itani RM, Sarfeh IJ, et al. Inhibition of angiogenesis by nonsteroidal anti-inflammatory drugs: insight into mechanisms and implications for cancer growthand ulcer healing. Nat Med. 1999;5:1418-23.

26. Hatazawa R, Tanaka A, Tanigami M, Amagase K, Kato S, Ashida Y, Takeuchi K. Cyclooxygenase-2/prostaglandin E2 accelerates the healing of gastric ulcers via EP4 receptors. Am J Physiol Gastrointest Liver Physiol. 2007;293:G788-G797.

27. Mizuno H, Sakamoto C, Matsuda K, Wada K, Uchida T, Noguchi H, et al. Induction of cyclooxygenase 2 in gastric mucosal lesions and its inhibition by the specific antagonist delays healing in mice. Gastroenterology. 1997;112:387-97.

28. Ukawa H, Yamakuni H, Kato S, Takeuchi K. Effects of cyclooxygenase- 2 selective and nitric oxide-releasing nonsteroidal antiinflammatory drugs on mucosal ulcerogenic and healing responses of the stomach. DigDis Sci. 1998;43:2003-11.

29. Andersen V, Nimmo E, Krarup HB, Drummond H, Christensen J, Ho GT, et al. Cyclooxygenase-2 (COX-2) polymorphisms and risk of inflammatory bowel disease in a Scottish and Danish case-control study. Inflamm Bowel Dis. 2011;17:937-46.

30. Zhang CX, Guo LK, Guo XF. Interaction between the polymorphisms of cyclooxygenase-2-1195G/A,MnSOD9Ala/val genes and the high-fat diets and its correlation with ulcerative colitis. Zhongguo Yi Xue Ke Xue Yuan Xue Bao 2015;37: 37-43.

31. de Vries HS, te Morsche RH, van Oijen MG, Nagtegaal ID, Peters $\mathrm{WH}$, de Jong DJ.The functional $-765 \mathrm{G} \rightarrow \mathrm{C}$ polymorphism of the COX2 gene may reduce the risk of developing crohn's disease. PLoS One. 2010;5:e15011.

32. Williams CS, Mann M, DuBois RN. The role of cyclooxygenases in inflammation, cancer, and development. Oncogene. 1999;8:7908-16.

33. Zhu W, Wei BB, Shan X, Liu P. $-765 \mathrm{G}>\mathrm{C}$ and $8473 \mathrm{~T}>\mathrm{C}$ polymorphisms of COX-2 and cancer risk: a meta-analysis based on 33 case-control studies. Mol Biol Rep. 2009;37:277-88.

34. Watanabe J, Lin JA, Narasimha AJ, Shahbazian A, Ishikawa T, Martin MG, et al. Novel anti-inflammatory functions for endothelial and myeloid cyclooxygenase-2 in a new mouse model of Crohn's disease. Am J Physiol Gastrointest Liver Physiol. 2010;298:G842G850. 